\title{
RUBRIEKEN
}

KRONIEK

\section{Recensie van Uri Rosenthal, Waarnemer, adviseur, beslisser*}

\author{
Hans de Bruijn
}

Uri Rosenthal is een van de meest toonaangevende Nederlandse hoogleraren Bestuurskunde van de afgelopen decennia - en dus verdient 'Waarnemer, adviseur, beslisser' een bespreking in Bestuurskunde.

Voordat ik mij daaraan zet, twee opmerkingen vooraf. De eerste is dat ik Uri persoonlijk ken. Hij was mijn promotor en hoewel wij na mijn promotie in 1990 slechts sporadisch contact hadden, is en blijft daar die band tussen promotor en promovendus. Het risico bestaat dus dat dit tot een bias in deze recensie leidt.

De tweede is dat een publicatie als deze zich lastig laat bespreken - om de eenvoudige reden dat je kunt twisten over de vraag aan welke eisen een autobiografie dient te voldoen. Dat betekent dat dit een recensie met een bescheiden ambitie is. Ik heb Rosenthals boek gelezen - en geef een aantal van mijn indrukken weer, zowel positief als kritisch.

In 'Waarnemer, Adviseur, Beslisser' beschrijft Rosenthal zijn professionele ontwikkeling - leerling aan het Maerlant Lyceum, student in Amsterdam, onderzoeker en hoogleraar aan de universiteiten van Amsterdam, Rotterdam en Leiden, directeur van het Crisis Observatie Team, adviseur, voorzitter van de VVD-fractie in de Eerste Kamer, informateur, minister van Buitenlandse Zaken in het kabinet-Rutte I - en ook daarna bekleedt hij een aantal belangrijke maatschappelijke posities.

Het boek is vooral het verhaal van en een reflectie op zijn professionele ontwikkeling. Over zijn persoonlijk wel en wee komen we weinig te weten. Slechts een enkele keer zegt hij iets over zijn persoonlijke relaties of over zijn gevoelens - en die passages zijn meestal erg kort. Tegelijk, die passages zijn vaak ook subtiel en treffend - als je er als lezer op let, zie je het. 'Er heerste alles bij elkaar geen feeststemming in de familie' toen het ministerschap van Rosenthal in Rutte I (VVD en CDA, gedoogd door Wilders) aanstaande was. Zijn dochters hadden liever dat hij zich distantieerde van Geert Wilders, in plaats van zich met hem op deze manier te associeren. Het is alsof hij zijn kritische dochters even de vloer wil geven in zijn boek. Ook typerend: hij bezoekt als minister een vluchtelingenkamp en beschrijft 
wat hij daar aantreft. Hij beschrijft dat heel feitelijk, maar sluit af met één woord: 'Hartverscheurend.'

Op deze constatering - vooral aandacht voor het professionele, minder voor het persoonlijke - is één grote uitzondering: in de proloog van het boek vertelt Rosenthal over het gezin waarin hij werd geboren. Het gaat over de Holocaust en over de vele gasten op de bruiloft van zijn ouders, die nooit zijn 'teruggekomen' (Rosenthal zet het woord zelf tussen aanhalingstekens). Over zijn vader, die nazidwangarbeid verricht in Frankrijk, zonder dat de nazi's weten dat hij Joods is. Over zijn moeder, die is ondergedoken in Lyon, en over de vlucht van het gezin naar Zwitserland, in 1944. Verder gaat het over de terugkeer van het gezin Rosenthal naar het Bezuidenhout, en de absurde houding van de Nederlandse overheid. Rosenthal citeert uit brieven van het ministerie van Binnenlandse Zaken waarin zijn vader - in perfecte bureaucratische taal - wordt gesommeerd om de kosten voor het verblijf in Zwitserland terug te betalen. Hij laat de woede van zijn vader zien over Frederik Weinreb. Weinreb was voor de oorlog bevriend met Rosenthals vader. Hij wordt na de oorlog veroordeeld wegens verraad, probeert zichzelf later te rehabiliteren met een boek, inclusief beschuldigingen aan het adres van vader Rosenthal. Het RIOD laat geen spaan heel van Weinrebs beweringen - maar ondertussen wordt hij al die tijd wel gesteund door intellectuelen als Renate Rubinstein en Jacques Presser. Het moet heel wat geweest zijn.

Ondanks dit alles en ondanks de naoorlogse armoede heeft de jonge Rosenthal een 'prettige lagere school tijd' en datzelfde geldt min of meer voor de jaren op het lyceum. Tijdens die jaren verslapt de band met het joodse geloof en wordt, bijvoorbeeld, de zaterdag een dag als alle andere dagen.

De familiegeschiedenis is natuurlijk een teer onderwerp - dus houd ik er eerbiedig afstand van. Maar één vraag dringt zich toch op - als lezer vraag je je af welke impact deze geschiedenis op Rosenthals denken heeft gehad. Afkeer van intellectuelen die zich met politiek bemoeien, zoals Bolkestein die bijvoorbeeld ook heeft? Voorkeur voor een kleine overheid? Afkeer van plan- en ontwerpdenken? Bepaalde opvattingen over tolerantie en de bescherming van minderheden? Het is gissen, want Rosenthal zegt er verder weinig tot niets over. Aan het einde van zijn boek staat een wat raadselachtige zin: 'Buiten Israel worden joodse ministers nog wel eens als vreemdelingen op de hot seats gezien.' Ik vond het moeilijk de precieze betekenis en vooral ook om de ernst van die zin te duiden.

Deel 1 en 2 van het boek gaan over de ontwikkeling van Rosenthal als onderzoeker. Het wordt onmiddellijk duidelijk dat wetenschap en bestuurskunde voor Rosenthal serieuze zaken zijn. Hij verhaalt met veel intellectuele passie over zijn onderzoek. De energie spat ervan af. Rosenthal is bepaald niet het type emeritus dat er na zijn vertrek uit de wetenschap achter komt dat het allemaal niet zo veel voorstelt, die bestuurskunde. Hij wil als wetenschapper de feiten boven water krijgen - en leert in de loop van zijn ontwikkeling om niet (alleen) te denken vanuit de wetenschap, die het openbaar bestuur uitlegt of voorschrijft wat het moet doen. Het gaat er, ook, om de politiek-bestuurlijke real world te doorgronden en die te verdisconteren bij de productie van wetenschappelijke kennis en adviezen. 
Die praktijk bestaat bijvoorbeeld uit voortmodderen en 'dingen niet zien, ze aan je voorbij laten gaan, niet beslissen'. Het is een filosofie waarmee hij veel invloed heeft uitgeoefend op de bestuurskunde. Voor de huidige generatie bestuurskundigen is die misschien vanzelfsprekend, maar het vakgebied had ook de kant kunnen opgaan van de traditionele beleidsanalyse: veel analyse en modelmatig denken, prachtige doel-middelen-schema's, maar geen aandacht voor politiekbestuurlijke rationaliteit en dus weinig impact.

Vervolgens geeft Rosenthal een overzicht van zijn grote onderzoeksthema: crisisbesluitvorming - een onderzoekslijn die bij toeval begon. Hij geeft een algemeen overzicht van de 'crisiswetenschap' en gaat zo ongeveer zijn hele portfolio aan crisis-onderzoek af: de ene crisis na de andere komt voorbij - ik vond het spannend om te lezen. Ik heb me ook nooit gerealiseerd dat er blijkbaar vanuit de wetenschap nogal eens kritiek kwam op dit onderzoek: het thema zou te perifeer zijn en de werkwijze (veel veldwerk) onvoldoende wetenschappelijk. Wat een flauw verwijt.

Ik veroorloof me twee kritische kanttekeningen bij de inhoudelijke beschrijving van het onderzoek.

De eerste heeft betrekking op de kritiek die er van politici en bestuurders komt op het crisis-onderzoek. Regelmatig meldt Rosenthal dat bestuurders het niet met zijn analyses en conclusies eens zijn of zelfs boos op Rosenthal c.s. zijn. Nu laat Rosenthal duidelijk zien wat wetenschappelijke integriteit betekent: je trekt alleen conclusies die door onderzoek worden gedragen, en die zijn vervolgens niet onderhandelbaar. Dat zal iedere bestuurskundige met hem eens zijn - en veel bestuurskundigen hebben van doen gehad met bestuurders die het anders zien dan uit onderzoek blijkt. Ik denk echter dat we niet moeten onderschatten welke enorme politieke turbulentie er hangt rond de thema's waarop Rosenthal onderzoek doet. Voor elk van de crises geldt dat je als onderzoeker telkens in het oog van de politieke orkaan zit - en dus onder enorme druk kunt komen te staan om je conclusies aan te passen.

Tegelijk, Rosenthal zet conflicten met bestuurders wel heel erg in de sleutel van 'speaking truth to power' - de onderzoekers hebben gelijk, de bestuurders willen dat niet onder ogen zien. Ik kan me dat bij onderzoek dat zo dicht op de politiekbestuurlijke werkelijkheid zit, niet voorstellen. Bestuurders moeten af en toe ook een vorm van gelijk aan hun zijde hebben gehad en er zullen patronen zijn in hun kritiek - die wil je als lezer weten, omdat ze helpen om je een oordeel te vormen over het crisis-onderzoek.

De tweede is dat ik het hoofdstuk over crisiswetenschap wat vond tegenvallen. Rosenthal refereert aan inmiddels algemeen bekende theorieën - normal accident, high reliability, groupthink - maar je bent als lezer ook benieuwd tot welke generieke inzichten zijn indrukwekkende portfolio leidt. Misschien was dat niet het doel van het hoofdstuk - maar er is meer dan de afzonderlijke crisis-onderzoeken.

Overigens gaat het in deze twee delen ook over de enorme variëteit aan andere werkzaamheden van Rosenthal - hij is decaan, NWO-bestuurder, adviseur, richt 
met Roel in 't Veld de NSOB op. Het boek geeft ook een tijdsbeeld van de grote veranderingen aan de academie. Ook interessant: Rosenthals belevenissen aan de Universiteit van Amsterdam - waar in naam van de revolutie wordt geïntimideerd en gemanipuleerd en heel veel vergaderd.

In deel 3 beschrijft Rosenthal zijn politieke carrière - van wat hand- en spandiensten voor de VVD, via Eerste Kamerlid en fractievoorzitter, tot informateur en Minister van Buitenlandse Zaken. Het gaat over de grote, buitenlandse politieke ontwikkelingen en de kleinheid van mensen die samen een partij vormen. Mooi is dat hij zijn ervaringen in de politieke arena vaak verbindt met de grote denkers over de staat. Van Hobbes heeft hij geleerd dat de kernfunctie van de staat het voorkomen van anarchie is, niet minder, maar ook niet meer. Aan Max Weber heeft hij overgehouden dat het veel uitmaakt of politici leven van de politiek of voor de politiek. Barents heeft hem de kern van democratie bijgebracht: de meerderheid beslist; de meerderheid respecteert de opvattingen van de minderheid; de minderheid respecteert de beslissingen van de meerderheid - en democratie begint en eindigt met respect voor de individuele rechten van mensen.

Mooi is ook de beschrijving van de 'uphill battle' van Mark Rutte, via het partijleiderschap naar premier. Het had allemaal anders kunnen lopen. Wat mij trof, is het diepe respect dat Rosenthal heeft voor Rutte. Hij spreekt erg warm over de premier, ook over zijn opvatting dat Nederland een 'gaaf' land is.

Ik haal drie dingen uit dit deel naar voren.

Het eerste betreft het rapport 'Liberaal Bestek 90', waaraan Rosenthal meewerkt en dat het liberalisme van de VVD tracht te positioneren. Het rapport wordt heel, heel kritisch ontvangen - door de andere partijen (die het rabiaat-rechts vinden), maar ook binnen de VVD. 'Tendentieus, ongenuanceerd, rommelig, eenzijdig, simplistisch, misplaatst' zijn de kwalificaties binnen de partij. Het rapport pleit voor een 'nuttigheids-liberalisme'. Rosenthal staat er nog volledig achter - het rapport was zijn tijd ver vooruit, zegt hij. Het is niet zo moeilijk om utiliteit-denken te bekritiseren als immoreel en plat - en dat gebeurt dus ook vaak. Rosenthal durft hier tegen de stroom in te gaan - en dat op zich verdient al waardering. Er zit ook iets in, in zijn constatering dat het rapport te vroeg kwam. Zo wordt de suggestie dat immigranten verplicht Nederlands moeten leren, hier en daar met hoon ontvangen. Maar ik had graag gezien dat hij wat meer woorden had genomen om het rapport inhoudelijk te verdedigen. Misschien wel juist omdat het utiliteit-denken nogal makkelijk wordt afgeschreven in het publieke debat.

Het tweede heeft betrekking op de korte notities die Rosenthal aan zijn partijgenoten schrijft - daar kon ik niet altijd chocola van maken. Bij veel van die notities zocht ik toch wat naar de betekenis ervan - wat maakte ze bijzonder voor de betreffende politici, wat was de context waardoor ze blijkbaar betekenisvol waren? Overigens komen er voor de fijnproevers veel interessante observaties voorbij - de legitimiteitscrisis van de overheid noemt hij bijvoorbeeld 'een lichte kwaal', ook weer tegen de stroom in.

En dan het derde: Rosenthals ministerschap. Wie het verslag daarvan leest, moet onmiddellijk denken aan het 'Events, my dear boy, events' van Harold Macmillan 
- niet je beleid bepaalt je ministerschap, maar de toevallige externe gebeurtenis; bij Rosenthal is dat bijvoorbeeld de Arabische lente, die geen lente bleek te zijn. Ook dit deel van het boek leest als een trein - Rosenthal schrijft echt heel helder en het lijkt wel of hij hier wat meer reflexief en kritisch naar zichzelf kijkt, dan in de andere delen van het boek. Ook hier gaat mijn kanttekening over zijn ideeën. Rosenthal beweert dat hij een nieuwe zakelijkheid in het buitenlands beleid heeft ingebracht - zijn voorganger Verhagen was er al voorzichtig aan begonnen, zijn opvolger Timmermans heeft het voortgezet. Hij verzet zich tegen te veel moralisme in de buitenlandse politiek. De wereld is geen Zwitserland, zegt hij - en dat klopt. De wereld is ook niet één grote Veluwe - dat klopt ook al, in de grote boze wereld moet je soms de duivel verdrijven met Beëlzebub. Ik had graag gezien dat Rosenthal ook dit gedachtegoed wat meer had uitgewerkt - over het gevaar van moralisme, over het soms immorele karakter van moralisme, en over de noodzaak van een soort realpolitik. Ook de claim dat hij nieuwe zakelijkheid heeft gebracht, had hij beter kunnen verdedigen. Ik ben te weinig deskundig om de claim te kunnen beoordelen - maar meen toch dat de tijden van moralistische buitenlandse politiek, als die ooit hebben bestaan, al lang voorbij zijn.

Ik moet eerlijk bekennen: toen ik vernam dat dit boek zou verschijnen, was ik wat sceptisch. De groten der aarde schrijven misschien een autobiografie - maar wij niet. Ik moet ook eerlijk bekennen: ik vind het een mooi boek. Het is de beschrijving van een rijk professioneel leven, in de publieke dienst. Van een wetenschapper die relevant wil zijn voor het openbaar bestuur - en van een bestuurder die op zijn ervaringen reflecteert, vanuit zijn wetenschappelijke kennis. 